\title{
KEPEMIMPINAN KEPALA MADRASAH DALAM UPAYA MENINGKATKAN MUTU PENDIDIKAN DI MAN 2 BATUSANGKAR KABUPATEN TANAH DATAR
}

\author{
${ }^{1}$ Nurlela, ${ }^{2}$ Marhen \\ ${ }^{1}$ Madrasah Aliyah Negeri 1 Batusangkar, ${ }^{2}$ IAIN Batusangkar \\ Korespondensi: Jl. Sungayang, Minangkabau, Sungayang, Kabupaten Tanah Datar, Sumatera Barat \\ e-mail: ${ }^{1}$ nayyahendri@gmail.com., ${ }^{2}$ marhen@iainbatusangkar.ac.id
}

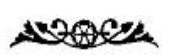

\begin{abstract}
This study aims to find out about the Principal's leadership in an effort to improve the quality of education and to look for the meaning behind the facts about the principal's leadership in an effort to improve the quality of education in MAN 2 Batusangkar Tanah Datar District. The method used in this study is qualitative, the research procedure with descriptive data results. Data collected by observation, direct interviews and documentation studies. The results of this study indicate that the Principal of MAN 2 Batusangkear has multiple leadership styles, in carrying out bis duties he is willing to accept suggestions from his subordinates and is willing to accept criticism for the success of joint work. The strategy used in general is a bridge between the existing buman resources, the division of tasks is given according to teacher competencies, there is a clear schedule, direct evaluation and indirect evaluation, and each teacher appreciates and helps each other. Although there are several obstacles, but these obstacles can be overcome properly.
\end{abstract}

Keywords: Kepemimpinan, Mutu Pembelajaran, MAN 2 Batusangkar

\section{PENDAHULAN}

Kepemimpinan dipahami sebagai segala daya upaya bersama untuk menggerakkan semua sumber daya dan alat (resources) yang tersedia dalam suatu organisasi. Resaouces tersebut dapat tergolongakan menjadi dua bagian besar, yaitu: buman resources dan non buman resources. Dalam lembaga pendidikan, khususnya lembaga pendidikan Islam yang termasuk salah satu unit organisasi juga terdiri dari berbagai unsur atau sumber daya, dan manusia merupakan unsur terpenting. Untuk itu, dapat dikatakan bahwa sukses tidaknya suatu organisasi untuk mencapai tujuan yang telah ditetapkan sangat tergantung atas kemampuan pemimpinnya untuk menumbuhkan iklim kerja sama dengan mudah dapat menggerakkan sumber-sumber daya yang ada sehingga dapat mendayagunakannya dan dapat berjalan secara baik. Dengan demikian kehidupan suatu organisasi sangat ditentukan oleh peran seorang pemimpin. Kepemimpinan yang efektif, mampu menumbuhkan dan mengembangkan usaha kerja sama serta memelihara iklim yang kondusif dalam kehidupan organisasi. Kepemimpinan yang baik adalah kepemimpinan yang dapat 
mengintegrasikan orientasi tugas dengan orientasi hubungan manusia.

Kepemimpinan kepala madrasah merupakan unsur vital bagi efektifitas lembaga pendidikan. Kepala madrasah yang baik akan bersikap dinamis untuk menyiapkan berbagai macam program pendidikan. Bahkan tinggi rendahnya mutu suatu sekolah akan dibedakan oleh kepemimpinan di Sekolah. Kepala madrasah memiliki peran yang kuat dalam mengkoordinasikan serta menggerakkan dan menyerasikan semua sumberdaya pendidikan yang tersedia di madrasah. Kepemimpinan kepala madrasah merupakan salah satu faktor yang dapat mendorong madrasah untuk dapat mewujudkan visi, misi, tujuan dan sasaran madrasah melalui program-program yang dilaksanakan secara terencana dan bertahap (Sulistiyorini, 2009).

Kepala madrasah sebagai pimpinan tertinggi yang sangat berpengaruh dan menentukan kemajuan sekolah harus memiliki kemampuan administrasi memiliki, komitmen tinggi dan luwes dalam melaksanakan tugasnya. Kepemimpinan kepala madrasah yang baik harus dapat mengupayakan peningkatan kinerja guru melalui program pembinaan kemampuan tenaga kependidikan. Oleh karena itu kepala madrasah harus mempunyai kepribadian atau sifat-sifat dan kemampuan serta keterampilan-keterampilan untuk memimpin sebuah lembaga pendidikan. Dalam perannya sebagai seorang pemimpin, kepala madrsasah harus dapat memperhatikan kebutuhan dan perasaan orang-orang yang bekerja, sehingga kinerja guru selalu terjaga (Yulia, 2013).
Kemampuan manajerial yang handal juga mampu membawa suasana madrasah yang sehat dan dinamis. Menciptakan sikap dan semangat serta profesionalisme guru juga banyak tergantung pada kepemimpinan kepala madrasah. Para guru atau staf lainnya akan dapat bekerja dengan baik dan penuh semangat bila kepala madrasah mampu menerapkan kepemimpinannya secara efektif. Oleh karena itu untuk meningkatkan profesionalisme guru perlu diperhatikan kepemimpinan kepala madrasah.

Dalam kajian manajemen pendidikan, kegiatan menggerakkan orang lain adalah kepemimpinan (leadership). Kepemimpinan yang menentukan arah dan tujuan, memberikan bimbingan dan menciptakan iklim kerja yang mendukung pelaksanaan proses administrasi secara keseluruhan dan kegiatan belajar mengajar.

Penilaian kinerja tentang kepemimpinan kepala madrasah dilaksanakan berdasarkan tugas pokok dan fungsi (Tupoksi). Tupoksi kepala madrasah juga harus mengacu pada Permendiknas Nomor 19 Tahun 2007 tentang standar pengelolaan sekolah, meliputi (1) perencanaan program, (2) pelaksanaan rencana kerja, pengawasan dan evaluasi, (4) kepemimpinan sekolah, (5) sistem informasi sekolah. Berdasarkan Permendiknas Nomor 28 Tahun 2010 tentang Penugasan Guru sebagai kepala sekolah/madrasah (Permendiknas Nomor 19 Tahun 2007).

Manajemen peningkatan mutu pendidikan di sekolah adalah suatu metode peningkatan mutu yang bertumpu pada pendidikan di sekolah itu sendiri, mengaplikasikan sekumpulan teknik, mendasarkan pada ketersediaan data kuantitatif 
dan kualitatif, dan pemberdayaan semua komponen sekolah secara berkesinambungan meningkatkan kapasitas dan kemampuan organisasi sekolah guna memenuhi kebutuhan peserta didik dan masyarakat (Yulia, 2013)

Terdapat dua faktor yang dapat menjelaskan mengapa upaya perbaikan mutu pendidikan selama ini kurang berhasil. Pertama, strategi pembangunan pendidikan selama ini lebih bersifat input oriented. Strategi yang demikian lebih bersandar kepada asumsi bahwa bilamana semua input pendidikan telah dipenuhi, seperti penyediaan buku-buku (bahan ajar), media dan alat belajar lainya, penyediaan sarana pendidikan, pelatihan guru dan tenaga kependidikan lainya, maka secara otomatis lembaga pendidikan atau sekolah akan dapat menghasilkan output yang bermutu sebagaimana yang diharapkan. Ternyata strategi input-output yang diperkenalkan oleh teori education production function, tidak sepenuhnya relevan di lembaga pendidikan atau sekolah, melainkan hanya terjadi dalam bidang ekonomi dan indrusti. Kedua, manajemen pendidikan selama ini lebih bersifat macro-oriented, diatur oleh jajaran birokrasi di tingkat pusat. Akibatnya, banyak faktor yang diproyeksikan di tingkat pusat tidak berjalan sebagaimana mestinya di tingkat sekolah/madrasah. Atau dapat dikatakan bahwa kompleksitasnya cakupan permasalahan pendidikan, sering kali tidak dapat terpikirkan secara utuh dan akurat oleh birokrasi pusat (Rusman, 2012).

Islam juga menuntut manusia untuk melakukan perubahan ke arah yang bermutu ketika melakukan sesuatu kegiatan. Hal ini sesuai dengan firman Allah dalam
QS: Al-Ra'du Ayat 11, 'Bagi manusia ada malaikat-malaikat yang selalu mengikutinya bergiliran, di muka dan di belakangnya, mereka menjaganya atas perintah Allah. Sesunggubnya Allah tidak merobah keadaan sesuatu kaum sehingga mereka merobah keadaan yang ada pada diri mereka sendiri. Dan apabila Allah menghendaki keburukan terhadap sesuatu kaum, maka tak ada yang dapat menolaknya; dan sekali-kali tak ada pelindung bagi mereka selain Dia.

Paparan ayat di atas, menuntut manusia harus melakukan perubahan ke arah yang posistif dan berkualitas. Karena Allah akan mengubah suatu keadaan ketika orangorang tersebut mau mengubah cara hidupnya, baik dari segi pemikiran, perbuatan dan tindakannya, sehingga menghasilkan mutu yang baik terhadap apa yang telah dilakukannya. Dalam menghasilkan mutu yang baik, teori menajemen mutu menjadi kebutuhan dalam mengelola lembagalembaga pendidikan dengan merencanakan program-program yang bermutu untuk guru dan siswa.

Pemetaan mutu pendidikan adalah langkah awal untuk memajukan pendidikan di Sumatera Barat. Pemetaan mutu itu meliputi pendidikan dasar dan menengah, atau bentuk pendidikan lain yang sederajat. Pemetaan mutu yang tepat akan sangat membantu perkembangan pendidikan, terutama dalam hal pendampingan. Selain itu, Dinas Pendidikan Sumatera Barat juga mengembangkan sistem informasi mutu pendidikan. Dinas Pendidikan Sumatera Barat mempunyai misi dalam pencapaian standar mutu pendidikan, yaitu dengan melakukan supervisi satuan pendidikan dasar dan menengah. Dengan demikian, 
standar mutu pendidikan di wilayah Sumatera Barat tidak jauh berbeda dengan standar pendidikan nasional. Dinas Pendidikan Sumatera Barat berusaha untuk memberi fasilitas kepada sumber daya pendidikan terhadap satuan pendidikan dasar dan menengah dalam usaha penjaminan mutu pendidikan di daerah setempat. Dinas Pendidikan Sumatera Barat juga berusaha meningkatkan profesionalisme sumber daya manusia di Sumatera Barat. Dengan tenaga pendidik yang profesional, tentu bukan hal yang mustahil untuk mewujudkan semua visi-misi pendidikan yang telah dicanangkan Dinas Pendidikan Sumatera Barat dari awal (http://disdikbud.sumbarprov.go.id/ diakses pada tanggal 02 Februari 2016).

Kementerian Agama Kabupaten Tanah Datar sebagai Instansi yang mengelola pendidikan di MAN 2 Batusangkar mempunyai visi sebagai berikut: "Terdepan dalam Prestasi, Terpuji dalam Berakhlak dan Terampil dalam Bekerja dan berbudaya Lingkungan". Untuk mewujudkan visi maka ditentukan misi sebagai berikut: meningkatkan kualitas kehidupan beragama, meningkatkan kualitas kerukunan umat beragama, meningkatkan kualitas Raudhatul Athfal, madrasah, perguruan tinggi agama, pendidikan agama, dan pendidikan keagamaan, meningkatkan kualitas penyelenggaraan ibadah haji, dan mewujudkan tata kelola kepemerintahan yang bersih dan berwibawa (http://kemenagtanahdatar.info/visi-misi $\angle$, diakses pada tanggal 02 Februari 2016)

MAN 2 Batusangkar sudah membawa perubahan ke arah yang positif dalam meningkatkan mutu sekolah. Hal ini dibuktikan dengan banyaknya programprogram keagamaan, sains, pramuka, olah raga dan seni yang sudah terealisasi. Adapun program yang sudah terealisasi adalah perkemahan pramuka antar pesantren Sumatera Barat, pelatihan kaligrafi, pembangunan kelas baru, pembangunan gedung seni dan lain-lain. Untuk meningkatkan mutu dalam bidang teknologi, MAN 2 Batusangkar sekarang sudah menyiapkan laboratorium komputer, yang bertujuan untuk menyiapkan peserta didik dalam menghadapi sistem komputerisasi di masa yang akan datang". (Wawancara dengan guru Keterampilan MAN 2 Batusangkar).

Dalam meningkatkan kualitas siswa terhadap penahamannya dalam pelajaran, MAN 2 Batusangkar menyeleksi guru sesuai dengan kompetensinya, bukan sekedar hanya memenuhi kuota jam pembelajarannya saja sebagai syarat untuk menerima tunjangan sertifikasi guru. MAN 2 Batusangkar sudah banyak memenangkan berbagai macam perlombaan baik tingkat kabupaten, propinsi dan tingkat nasional, seperti diutusnya siswa MAN 2 Batusangkar untuk mengikuti perlombaan pidato bahasa Arab di tingkat nasional, siswa tersebut adalah merupakan utusan propinsi Sumatera Barat dan juga ada seorang guru dari MAN 2 Batusangkar yang dipercayakan oleh pemerintah untuk menyusun naskah soal Ujian Nasional di Jakarta" (Wawancara dengan kepala madrasah MAN 2 Batusangkar)

\section{KEPEMMPINANKEPALAMADRASAH}

Kepemimpinan merupakan hal penting dalam organisasi. Suatu organisasi memiliki kompleksitas, baik barang/jasa maupun ide, 
menghadapi berbagai perubahan yang senantiasa melingkupi setiap saat, menghadapi berbagai karakteristik personel yang dapat mengembangkan maupun melemahkan. Hal ini menjadi alasan diperlukannya orang yang tampil mengatur, memberi pengaruh, menata, mendamaikan, memberi penyejuk, dan dapat menetapkan tujuan yang tepat saat anggota tersesat atau kebingungan menetapkan arah. Disinilah perlunya pemimpin yang melaksanakan kepemimpinan (Komariah, 2006)

Ada banyak pendapat yang mengemukakan tentang pengertian kepemimpinan, di antaranya adalah:

1. Menurut Siagian, kepemimpinan adalah kekuatan (power) yang didasarkan atas tabiat/watak seseorang yang memiliki kekuasaan lebih, biasanya bersifat normatif. Pengertian kepemimpinan juga diungkapkan oleh Siagian, yang menyebutkan bahwa kepemimpinan adalah motor atau daya penggerak daripada sumber-sumber dan alat-alat (resources) yang tersedia bagi suatu organisasi (Siagian, 1980)

2. Menurut Mardjin kepemimpinan adalah keseluruhan tindakan guna mempengaruhi serta menggiatkan orangorang dalam usaha bersama untuk mencapai tujuan, atau dengan definisi lain yang lebih lengkap dapat dikatakan kepemimpinan adalah proses pemberian bimbingan (pimpinan) atau teladan dan pemberian jalan yang mudah (fasilitas) daripada pekerjaan orang lain yang terorganisir dalam organisasi formal guna mencapai tujuan yang telah ditetapkan (Mardjin, 1966).
Kepemimpinan merupakan salah satu bagian dari manajemen. Meskipun demikian keduanya saling melengkapi. Beberapa perbedaan antara manajemen dan kepemimpinan menurut Mardjin, antara lain: (a) manajemen berhubungan dengan usaha menanggulangi kompleksitas, kepemimpinan menanggulangi perubahan; (b) manajemen berkaitan dengan perencanaan dan penganggaran untuk mengatasi kompleksitas, kepemimpinan mengenai penentuan arah perubahan melalui pembentukan visi; (c) manajemen mengembangkan kemampuan untuk melaksanakan rencana melalui pengorganisasian dan penyusunan staf, kepemimpinan mengarahkan orang untuk bekerja berdasarkan visi; (d) manajemen menjamin pencapaian rencana melalui pengendalian dan pemecahan masalah, kepemimpinan memotivasi dan mengilhami orang agar berusaha melaksanakan rencana. Oleh karena itu agar kepemimpinan kepala madrasah dapat efektif, maka kepala madrasah selaku pemimpin di lembaganya diharapkan mampu menyeimbangkan antara aktivitas manajerial dan aktivitas kepemimpinannya (Mardjin, 1966).

\section{KEPALAMADRASAH}

Kepala madrasah merupakan suatu faktor yang terpenting dalam proses pencapaian, keberhasilan sekolah dalam pencapaian tujuannya. Dengan demikian kepala madrasah sangat diharapkan pengaruhnya untuk mengendalikan agar pendidikan berjalan sesuai harapan semua pihak. Dalam menjalankan kepemimpinannya kepala madrasah tergantung kepada 
guru, karena guru merupakan ujung tombak pelaksanaan pendidikan (Nunu, 2007).

Secara etimologi menurut kamus besar bahasa Indonesia, kepala madrasah adalah orang atau guru yang memimpin suatu Sekolah (Departemen Pendidikan dan Kebudayaan RI, 1995). Sedangkan menurut Wahjosumidjo mengemukakan pengertian kepala madrasah adalah sebagai seorang tenaga profesional guru yang diberi tugas untuk memimpin suatu Sekolah di mana diselenggarakan proses belajar mengajar "atau" tempat dimana terjadi interaksi antara guru yang memberi pelajaran dan murid yang menerima pelajaran (Wahjosumidjo, 1999).

Definisi lain tentang pengertian kepala madrasah adalah Orang yang bertugas sebagai pemegang polisi umum dalam menentukan kebijakan di lingkungan Sekolah". Di samping sebagai seorang pemimpin kepala madrasah juga merupakan seorang bawahan yang harus mempertanggung jawabkan hasil yang dipimpinya kepada orang atau lembaga yang menunjuknya. Hal ini sabagaimana yang ditegaskan oleh Wahjosumidjo bahwa kepala madrasah adalah seseorang yang bertanggung jawab kepada atasannya terhadap tugas yang telah dipikulkan kepadanya pada lingkungan lembaga pendidikan" (Wahjosumidjo, 1999).

Dalam usaha untuk memenuhi kebutuhan lembaga pendidikan yang dipimpinnya tersebut, seorang kepala madrasah mempunyai tugas praktis. Dalam hal ini Hadari Nawawi (1988), menyatakan bahwa di antara tugas praktis yang harus dipedomani seorang kepala madrasah adalah:
1. Mengembangkan dan menyalurkan kebebasan berfikir dan mengeluarkan pendapat, baik secara individu maupun secara kelompok bagi guru dan perangkat sekolah.

2. Mengembang suasana kerjasama yang efektif dengan memberikan penghargaan dan pengakuan terhadap kemampuan orang-orang yang dipimpin.

3. Mengusahakan dan mendorong terjadinya pertemuan pendapat/-buah pikiran dengan sikap menghargai sehingga timbul perasaan ikut terlibat dalam usaha pencapaian tujuan pendidikan.

4. Membantu menyelesaikan masalahmasalah, baik yang dihadapi secara perseorangan ataupun kelompok dengan memberikan petunjuk-petunjuk dalam mengatasinya.

\section{MUTUPENDIDIKAN}

Menurut Arcaro (2007), mutu adalah sebuah proses terstruktur untuk memperbaiki keluaran yang dihasilkan dan didasari upaya positif yang dilakukan individu. Jadi setiap individu mempunyai peran yang sangat penting dalam menghasilkan sesuatu.

Mutu juga diartikan sebagai gambaran dan karakteristik menyeluruh dari barangatau jasa yang menunjukkan kemampuannya dalam memuaskan kebutuhan yang ditentukan atau yang tersirat (Nevizond Chatab, 1997). Dalam artian apa yang diberikan sesuai dengan kebutuhan pemakai dan dapat diandalkan.

Sedangkan menurut pandangan Juran, mutu dapat dijamin dengan cara memastikan bahwa setiap individu memiliki 
bidang yang diperlukan untuk menjalankan pekerjaan dengan tepat.

Dengan perangkat yang tepat para peke rja akan membuat produk dan jasa yang secara konsisten sesuai dengan harapan kostumer (Chatab, 1997). Sallis, menyatakan bahwa mutu merupakan suatu ide yang dinamis. Sedangkan definisi yang kaku sama sekali tidak membantu (Sallis, 2007). Oleh karenanya dia mendefinisikan mutu dalam dua konsep, yakni konsep yang absolut dan konsep relatif.

Pertama, konsep absolut tentang mutu yakni dalam artian mutu dalam percakapan sehari- hari sering difahami sebagai sesuatu yang absolut, yang mana mutu sama halnya dengan sifat baik, cantik dan benar. Sesuatu yang bermutu merupakan bagian dari standar yang sangat tinggi, yang tidak dapat diungguli. Produk-produk yang bermutu adalah sesuatu yang dibuat dengan sempurna dan dengan biaya yang mahal. Produk-produk tersebut dapat dinilai serta membuat puas dan bangga para pemiliknya. Mutu dalam pandangan ini digunakan untuk menyampaikan keunggulan status dan posisi kepemilikan terhadap sesuatu yang memiliki mutu akan membuat pemiliknya berbeda dengan orang lain yang tidak mampu memilikinya, mutu dalam pengertian ini disebut dengan bigh quality atau top quality (mutu tinggi).

Kedua, konsep relatif tentang mutu, definisi relatif memandang mutu bukan sebagai suatu akibat produk atau layanan, tetapi suatu yang dianggap berasal dari produk atau layanan tersebut. Mutu dapat dikatakan ada apabila sebuah layanan memenuhi spesifikasi yang ada dan meru- pakan sebuah cara yang menentukan apakah produk terakhir sesuai dengan standar atau belum. Produk atau layanan dalam kosep ini tidak harus mahal dan eksk lusif. Produk tersebut dapat cantik, tetapi tidak harus selalu demikian dan tidak ha rus asli, wajar dan familiar. Mutu memiliki dua aspek. Pertama adalah menyesuaikan diri dengan spesifikasi dan kedua adalah memenuhi kebutuhan pelanggan.

Standar Nasional Pendidikan adalah kriteria minimal tentang sistem pendidikan di seluruh wilayah hukum Negara Kesatuan Republik Indonesia, bahwa Peraturan Pemerintah Nomor 19 Tahun 2005 tentang Standar Nasional Pendidikan perlu diselaraskan dengan dinamika perkembangan masyarakat, lokal, nasional, dan global guna mewujudkan fungsi dan tujuan pendidikan nasional maka pemerintah telah menerbitkan Peraturan Pemerintah (PP) terbaru sebagai perubahan atas PP No. 19 Tahun 2005. PP tersebut adalah PP No. 32 Tahun 2013. SNP dipenuhi oleh satuan atau program pendidikan dan penyelenggara satuan atau program pendidikan secara sistematis dan bertahap dalam kerangka jangka menengah yang ditetapkan dalam rencana strategis satuan atau program pendidikan. Ruang Lingkup Standar Nasional Pendidikan meliputi: isi, proses, kompetensi lulusan, pendidikan dan tenaga kependidikan, sarana dan prasarana, pengelolaan, pembiayaan pendidikan dan penilaian pendidikan.

Pendidikan yang bermutu adalah pendidikan yang menghasilkan lulusan yang memiliki kemampuan atau kompetensi. Baik kompetensi akademik maupun kompetensi kejuruan, yang dilandasi oleh kompetensi 
personal dan sosial, yang secara menyeluruh disebut sebagai kecakapan hidup (life skill). Pendidikan kecakapan hidup adalah pendidikan bermutu, baik quality in fact maupun quality in perception. Untuk dapat meningkatkan mutu pendidikan, madrasah harus dapat melaksanakan pengelolaan yang didasarkan pada peningkatan mutu pendidikan madrasah. Peningkatan mutu harus bertumpu pada lembaga pendidikan untuk secara terus-menerus dan berkesinambungan untuk meningkatkan kapasitas dan kemampuan organisasinya guna memenuhi tuntutan dan kebutuhan peserta didik dan masyarakat. Dalam menajemen peningkatan mutu terkandung upaya: (1) mengendalikan proses yang berlangsung di lembaga pendidikan, baik kurikuler maupun administrasi, (2) melibatkan proses diagnosis dan proses tindakan untuk menindaklanjuti diagnosis, (3) peningkatan mutu harus didasarkan atas data dan fakta, baik yang bersifat kualitatif maupun kuantitatif, (4) peningkatan mutu harus dilasanakan secara terus-menerus dan berkesinambungan, (5) peningkatan mutu harus memberdayakan dan melibatkan semua unsur yang ada di lembaga pendidikan, dan (6) peningkatan mutu memiliki tujuan yang menyatakan bahwa sekolah atau madrasah dapat memberikan kepuasan kepada peserta didik, orangtua, dan masyarakat (Mutohar, 2013: 277).

\section{METODE PENEUTIAN}

Penelitian ini merupakan penelitian lapangan (field research), yaitu tinjauan terhadap berbagai fakta yang terjadi di lapangan penelitian. Dalam hal ini, penulis mengungkapkan tentang kepemimpinan kepala madrasah dalam upaya meningkatkan mutu pendidikan di MAN 2 Batusangkar Kabupaten Tanah Datar. Sedangkan dalam pembahasan artikel ini penulis menggunakan metode kualitatif, yaitu penelitian yang mengemukakan fakta-fakta yang terjadi di lokasi penelitian. Fakta yang akan diungkapkan dalam penelitian ini berkenaan dengan berbagai data kualitatif yang terkait kepemimpinan kepala madrasah dalam upaya meningkatkan mutu pendidikan di MAN 2 Batusangkar.

Data yang dikumpulkan melalui observasi ini berkenaan dengan data tentang kepemimpinan kepala madrasah dalam upaya meningkatkan mutu pendidikan di MAN 2 Batusangkar Kabupaten Tanah Datar. Data ini diperoleh secara langsung dari guru dan peserta didik itu sendiri, karena kedua sumber data inilah yang diobservasi. Observasi yang penulis lakukan dalam penelitian ini adalah observasi pasif dan observasi terlibat. Hal ini disebabkan penulis adalah sebagai peneliti dari permasalahan yang dibahas. Untuk mendapatkan data yang diperlukan melalui observasi, maka penulis menggunakan pedoman observasi sebagai instrumennya.

Wawancara dalam penelitian ini merupakan cara untuk mengumpulkan atau mendapatkan informasi melalui komunikasi langsung antara peneliti dengan objek yang diteliti, yaitu wawancara dengan sumber data primer seperti kepala madrasah itu sendiri dan wawancara dengan sumber data sekunder yaitu, guru, komite, tenaga administrasi dan peserta didik di MAN 2 Batusangkar. Selain itu, wawancara adalah suatu bentuk komunikasi verbal berupa percakapan yang bertujuan memperoleh 
informasi. Pertanyaan dan jawaban diberikan secara verbal, dilakukan dalam keadaan saling berhadapan, dapat juga dilaksanakan melalui telepon. Hubungan dengan yang diwawancarai bersifat sementara dalam jangka waktu tertentu dan kemudian diakhiri.

Dokumen yang peneliti jadikan rujukan di MAN 2 Batusangkar merupakan catatan peristiwa yang sudah berlalu, bisa berbentuk tulisan, gambar, atau karya-karya monumental dari seseorang mengenai kepemimpinan kepala madrasah dalam upaya meningkatkan mutu pendidikan di MAN 2 Batusangkar Kabupaten Tanah Datar. Dokumen yang berbentuk tulisan misalnya catatan harian, sejarah kehidupan (life bistories), cerita, biografi, peraturan dan kebijakan.

\section{HASIL PENEUTIANDAN PEMBAHASAN}

Gaya Kepemimpinan Kepala Sekolah dalam meningkatkan mutu pendidikan di MAN 2 Batusangkar adalah (1). Kepala sekolah MAN 2 Batusangkar memilki multi gaya kepemimpinan, dalam melaksanakan tugasnya pemimpin semacam ini mau menerima saran-saran dari bawahannya dan bahkan kritikankritikan dimintanya dari mereka demi suksesnya pekerjaan bersama. (2). Dalam memimpin para guru maupun karyawan, Kepala sekolah MAN 2 Batusangkar lebih banyak memberikan dorongan untuk meningkat prestasi maupun profesionalitas sehingga dalam upaya memajukan lembaga pendidikan melibatkan partisipasi anak buah dalam berbagai kegiatan. (3). Sebagai dorongan untuk berprestasi dan meningkatkan etos kerja bagi para guru dan karyawan, Kepala sekolah MAN 2 Batusangkar selalu memperhatikan imbalan matreri sesuai dengan kemampuan dana yang ada serta tingkat prestasi yang diraih, oleh karenanya ia bukan sekedar kharismatik, bukan sekedar partisipatif tetapi juga memiliki gaya kepemimpinan transaksianal.

Strategi Kepemimpinan Kepala Sekolah dalam meningkatkan mutu pendidikan di MAN 2 Batusangkar adalah (1). Jembatan hati mengesuaikan visi dan misi yang telah ditentukan bersama sehingga menjadikan sekolah adalah rumah kedua setah rumah yang di miliki guru-guru, jadi hati guru-guru dapat menagtu ketika menjalan kan tugas yang telah ditentukan. (2). Pembagian tugas yang sesuai dengan kopetensi guru yang ada sehingga tidak ada yang satupun tugas yang tertinggal. (3). Ada jadwal yang jelas, bukan sekedar pembagian tugas PBM saja tapi semua tugas yang ada dari adminitrasi sampai ke tugas satpam yang ada. (4). Evaluasi langsung dan evaluasi yang tidak langsung. Sesudah evaluasi setiap guru diakasih pengayan dan dan berbaikan. Jadi kalu guru yang baik akan diberi riot kepada guru yang berprestasi. (5). Setiap guru saling mengahargai dan saling membantu.

Kendala Kepemimpinan Kepala Seko-lah dalam meningkatkan mutu pendidikan di MAN 2 Batusangkar adalah (1). Kendala Internal, yang meliputi Pertama, bidang pembelajaran masih banyaknya SDM, belum terbentuk kelompok-kelompok per mata pelajaran, 
sehingga wawasan dan pengalaman SDM kurang optimal, padahal dengan banyknya sharing SDM yang ada akan memperkaya model dan strategi pembelajaran, sehingga peningkatan mutu pendidikan akan terwujud secara perlahan nantinya. Kedua, Minimnya dan sangat terbatasnya asistensi pendanaan di MAN 2 Batusangkar untuk melaksanakan kegiatan serta susahnya memperoleh dana ope-rasional menjadikan tidak adanya jaminan bahwa program yang positif akan memperoleh respons yang positif dan apresiasi yang memadai. Ketiga, Secara kelembagaan, MAN 2 Batusangkar dalam merancang anggaran tidak memiliki otonomi, otoritas dalam pelaksanaan program terbatas dan masih ditentukan dari pusat. Keempat, Besarnya jumlah SDM dan Input di MAN 2 Batusangkar untuk meningkatkan prestasi lembaga Madrasah ini tidak selalu dapat dimanfaatkan dengan baik sebagai kesempatan berkontribusi untuk melakukan perubahan di lembaga pendidikan agama (madrasah). (2). Kendala Eksternal, yang meliputi, Pertama, Kerja-sama dengan pemerintah daerah dalam konteks pendidikan keagamaan masih sebatas koordinasi dan belum berwujud kerjasama yang erat mulai dari perancangan, pendanaan, pelaksanaan kegiatan, sampai monitoring dan evaluasi kegiatan. Kedua, Program peningkatan mutu lembaga yang bernaung di bawah nama Madrasah dalam bidang keagamaan sering kali tidak berdaya menghadapi arus Globalisasi yang sudah mendunia, pada akhirnya orientasi masya-rakat hanya masalah keduniaan semata.
Menurut Victor, seorang pemimpin harus mengembangkan kepemimpinannya yang terdiri atas perbuatan-perbuatan yang selalu ada isinya, artinya yang tidak mengecewakan orang-orang yang bersangkutan dalam harapan-harapan mereka. Semakmin tinggi tingkat seseorang dalam kelompok, dan semakin mendekati kese-suaian kegiatannya dengan norma-norma kelompok, maka semakin luas jangkauan interaksinya dan semakin besar jumlah anggota kelompok yang bergerak. Namun harus dijaga agar aksi-aksi pemimpin itu tidak mengecewakan harapan-harapan pengikutnya/ kelompok. Teori ini memakai nama yang berlainan (Victor, 1964).

Peningkatan mutu harus bertumpu pada lembaga pendidikan untuk secara terus-menerus dan berkesinambungan untuk meningkatkan kapasitas dan kemampuan organisasinya guna memenuhi tuntutan dan kebutuhan peserta didik dan masyarakat. Dalam menajemen peningkatan mutu terkandung upaya: (1) mengendalikan proses yang berlangsung di lembaga pendidikan, baik kurikuler maupun administrasi, melibatkan proses diagno-sis dan proses tindakan untuk menindak-lanjuti diagnosis, (3) peningkatan mutu harus didasarkan atas data dan fakta, baik yang bersifat kualitatif maupun kuantitatif, (4) peningkatan mutu harus dilasanakan secara terus-menerus dan berkesinambung-an, (5) peningkatan mutu harus mem-berdayakan dan melibatkan semua unsur yang ada di lembaga 
pendidikan, dan (6) peningkatan mutu memiliki tujuan yang menyatakan bahwa sekolah atau madrasah dapat memberikan kepuasan kepada peserta didik, orangtua, dan masyarakat (Mutohar, 2013: 277).

\section{PENUTP}

\section{Kesimpulan}

Kepala sekolah MAN 2 Batusangkar memilki multi gaya kepemimpinan, dalam melaksanakan tugasnya sebagai pemimpin di sekolah. Hal ini dilakukan tergantung situasi dan kondisi di lapangan. Kepala sekolah MAN 2 Batusangkar mempunyai strategi khusus dalam memimpin di sekolah. Berbagai macam strategi dilakukan oleh kepala sekolah MAN 2 Batusangkar untuk meningkatkan mutu sekolah. Walaupun kepala sekolah MAN 2 Batusangkar mengalami berbagai kendala baik internal maupun eksternal, namun hampir semua kendala tersebut dapat diatasi dengan baik.

\section{Saran}

1. Diharapkan kepada Dinas Pendidikan dan Kemenag Kabupaten Tanah Datar agar selalu membina secara kontiniutas tentang Kepemimpinan Kepala Sekolah dalam Upaya Meningkatkan Mutu Pendidikan di MAN 2 Batusangkar Kabupaten Tanah Datar.

2. Diharapkan kepada komite sekolah dan tokoh-tokoh masyarakat selalu melibatkan diri dalam memberikan masukan-masukan pada perkembagan kualitas pendidikan MAN 2 Batusangkar Kabupaten Tanah Datar.
3. Diharapkan kepada pengawas Madrasah Aliyah Kabupaten Tanah Datar agar secara berkala membimbing Kepala MAN 2 Batusangkar Kabupaten Tanah Datar dan guru dalam pengajaran, demi tercapainya tujuan madrasah.

\section{KEPUSTAKAANACUAN}

Departemen Pendidikan dan Kebudayaan RI, 1995. Kamus Besar Bahasa Indonesia, (Edisi Kedua (Jakarta: Balai Pustaka,)

John W. Newstrom, Keith and Davis, 1990. Perilaku dalam Organisasi (Jakarta: Erlangga)

Komariah Aan, Cepi Triatna, 2006. Visionary Leadership (Jakarta: PT. Bumi Aksara)

Mardjin Sjam, 1966. Kepemimpinan dalam Organisasi (Surabaya: Yayasan Pendidikan Practice)

Nawawi Hadari, 1988. Administrasi Pendidikan, Cet. ke-6, (Jakarta: Haji Mas Agung)

Nevizond Chatab, 1997. Mendokumetasikan Sistem ISO 9000, (Yogyakarta: Andi)

Nuchiyah Nunu, Pengaruh Kepemimpinan Kepala Sekolah dan Tenaga Mengajar Guru Terhadap Prestasi Belajar Siswa, dalam "JURNAL, Pendidikan Dasar" Volume : V - Nomor : 7 - April 2007

Racmawati Yulia, 2013, Pengaruh Kepemimpinan Sekolah Terbadap Kinerja Guru, dalam Jurnal Pendidikan, Vol. 01 No. 01, Juni 2013

Rusman, 2012. Manajemen Kurikulum, (Jakarta: Raja Grafindo Persada) 
Sondang P. Siagian, 1980. Filsafat Prim Masrokan, 2013. Mutohar. Manajemen Administrasi (Jakarta: Gunung Agung)

Sulistiyorini, 2009. Manajemen Pendidikan Mutu Sekolah. (Jogjakarta: Ar-Ruzz Media)

Islam: Konsep Strategi dan Aplikasinya, Wahjosumidjo, 1999. Kepemimpinan Kepala (Yogyakarta: Teras)

madrasah Tinjauan Teoritik dan

Permasalaban, Jakarta: Raja Grafindo Persada) 